Рад примљен: 14. 12. 2013.

Рад прихваћен: 18. 03. 2014.

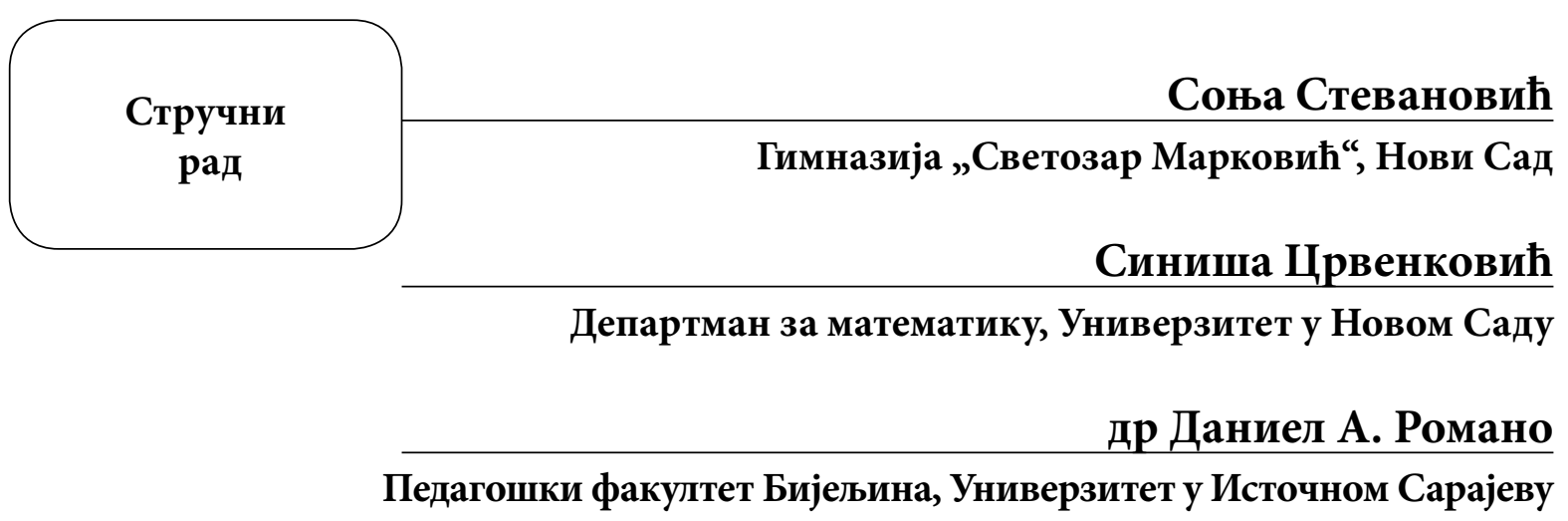

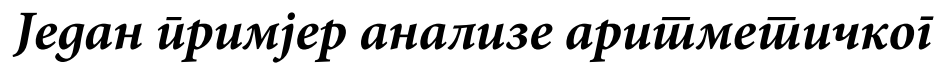 и раноалїебарскої мишъења
}

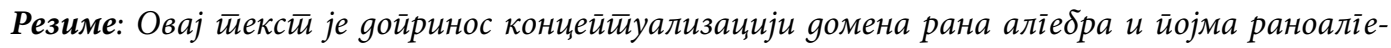

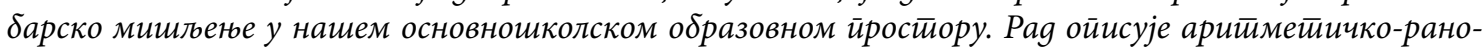

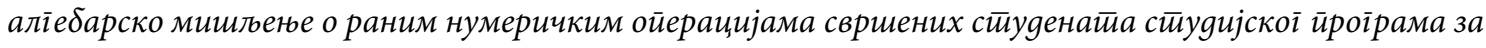

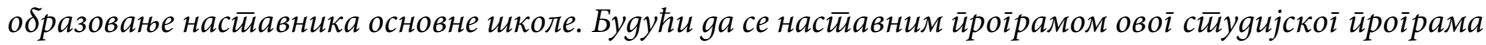
очекује оg сйуgенайа gа се баве аліебарским ияејама које се оgносе на мноіе концейие са йриродним

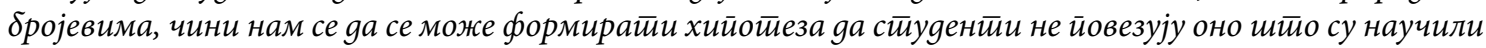

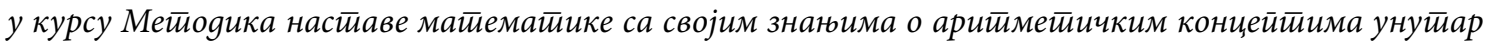

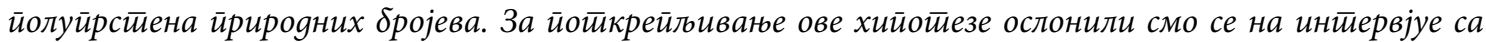

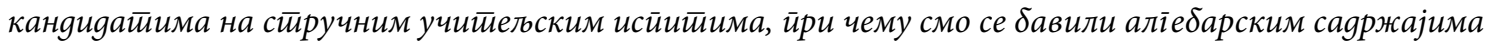

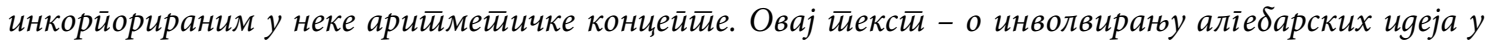

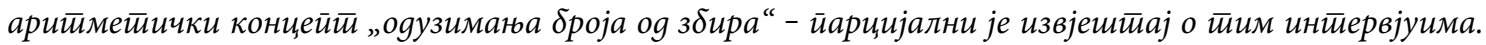

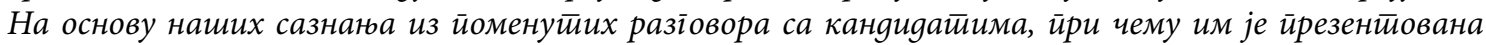

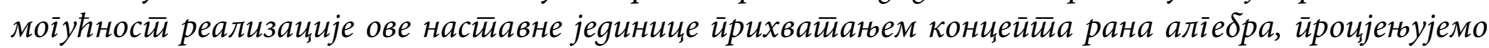

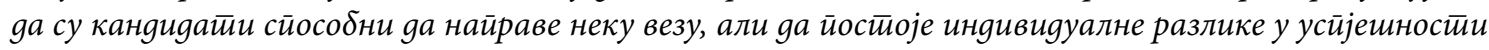
у иичм конекиијама.
\end{abstract}

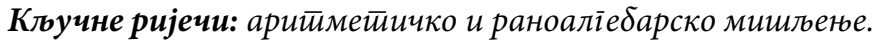


Увод

Уколико треба учитељи да у потпуности разумију садржај наставних програма математике којима подучавају своје ученике, вјерујемо да треба њихово разумијевање да се односи на разумијевање структура које стоје у позадини рада са природним бројевима, дакле алгебре. Ми вјерујемо да је суштина алгебре структура а не употреба слова за означавање варијабли. Уочавање структура и њихово описивање потпомаже развоју алгебарског мишљења. Јачање разумијевања веза између вербалних и симболичких описа неке математичке структуре у датом окружењу такође подстиче развој алгебарског мишљења. При томе се мисли на разумијевање особина операција сабирања и множења у скупу природних бројева (у овом тексту, кад говоримо о скупу $\mathbf{N}$ природних бројева, мислимо на скуп $\{0,1,2,3, \ldots\})$ као функција (свака за себе на јединствен начин, које једном пару природних бројева придружује тачно један природан број) и њихове везе са својствима бројева, на примјер асоцијативности и комутативности и везе између њих, тј. дистрибутивности. Ако се ово опише као чињенице дате формулама,

$$
\begin{gathered}
a+b=b+a, a \cdot b=b \cdot a \\
a+(b+c)=(a+b)+c, a \cdot(b \cdot c)=(a \cdot b) \cdot c \\
a \cdot(b+c)=a \cdot b+a \cdot c
\end{gathered}
$$

вјероватно да неће помоћи ученицима да схвате својства ових односа. Многи истраживачи математичког образовања (на примјер, Molina, Castro and Ambrose, 2005) вјерују да ученици могу сами да схвате суштину начина на који посматрају понашање природних бројева у односу на ове двије операције. Ако ученици при томе желе да на што јаснији начин искажу бројеве заједно са тим везама (тј. уочену структуру), кодификација њихових описа путем језика алгебре снажно ће подстицати развој њиховог алгебарског мишљења.
Садашњи начин, којим ученике нижих разреда основне школе подучавамо употреби слова као алгебарских варијабли и непознаница, своди се на кориштење варијабле $x$ како би се описало празно мјесто у аритметичким записима и рјешавање простих једначина и неједначина у скупу природних бројева и не подстиче развој алгебарског мишљења код ученика. Ријеч је још увијек о аритметичким структурама и, према томе, о аритметичком мишљењу. Оно што желимо да истакнемо је дубље разумијевање аритметике засновано на инволвирању алгебарских садржаја у аритметичке структуре, тј. на ученичком препознавању алгебарских темеља тих аритметичких структура.

У току учитељског стручног испита посматрана је реализација наставе јединице „Одузимање броја од збира“. У анализи одржаних часова са кандидатима расправљано је о могућностима које нуди обавезни уџбеник математике за трећи разред основне школе у Републици Српској, али и могућностима које омогућава алгебарски приступ проблему. С тим циљем, презентована је могућа реализација те наставне јединице и инволвирање алгебарског аспекта у аритметичку процедуру одузимања броја од збира.

Овај текст, као наш допринос концептуализацији домена рана аліебра и појма раноаліебраско миштеюе, иако је намјењен студентима другог циклуса учитељског програма, може бити користан и другим заинтересованим за дубље разумијевање ова два теоријска конструкта.

\section{Теоријска заснованост}

Многи истраживачи математичког образовања (на примјер: Џон Мејсон (Mason, 2012), Роберт Бењамин Дејвис (Davis, 1964), Ален Шенфилд (Alan Schoenfeld), Лесли Ли (Lee, 1996), Џејмс Капут (Kaput, 1999), Лесли Бут (Booth, 1989)) снажно су исказивали своју суздржаност о примјени традиционалног учење алгебре. Те 
критике су засноване на истраживањима неуспјеха великог броја ученика и студената (под термином с $\bar{u} y g e н \bar{u} u$ подразумијевају се полазници студијског програма за образовање професора разредне наставе) у учењу и подучавању алгебре. Према изнесеном ставу Мартина Кинда (Kindt, 1980), могу се препознати три главна проблема учења алгебре: недостатак пажње на генерализацијама аритметичких концепата, пракса да се пребрзо улази у учење формалне алгебре, али и несагледавање методских разлога за кога и за шта је корисно инволвирање алгебре у нижим разредима основне школе.

Незадовољство учењем алгебре, препознавање значаја алгебарског начина размишљања, али и потреба да се код свих студената развије способност разумијевања алгебре довела је до тога да универзитетски предавачи алгебарских садржаја траже и проналазе ефикасније начине предавања алгебре. У последње вријеме забиљежен је већи број предлога у том правцу као што су: базирање учења алгебре на рјешавању проблема и инволвирање алгебарских садржаја у аритметичке структуре. Чини се да истраживачи математичког образовања данас узимају у обзир шири концепт алгебре који би требало интегрисати у наставне програме математике за ученике нижих разреда основне школе. О алгебри се више не размишља као о предмету већ као о начину размишљања али и дјеловања на математичке објекте. Овај концепт, познат као рана аліе $р р а$, требало би да подржава не само ресорно министарство већ и академска заједница реализатора наставе математике у нашим основним школама, будући да алгебра има потенцијал да обогати математичке активности те да служи као водиља за промовисање учења са разумијевањем. У складу са овим предлогом, требало би учитељи да подстичу алгебарско размишљање док подучавају своје ученике аритметици те да им помажу да обрате пажњу не само на нумеричке објекте већ и на њихове међусобне односе. Према тврдњама из- ложеним у текстовима Марије Блантон и Џејмca Капута (нпр. Blanton and Kaput, 2003), требало би реализатори наставе математике да настоје да дизајнирају такву наставну атмосферу у учионици у којој би се вредновало ученичко моделовање, истраживање, учешће у расправама, предвиђање, вјештине прављења конекција, тестирање туђих идеја, али и увјежбавање процјењивачких вјештина. Ове пожељне интеракције могу се испровоцирати тако што би се ученицима постављала питања која би им помагала да вербализују своја мишљења о математичким објектима и њиховим међусобним везама са којима раде. На примјер, питања као што су: Да ти можейе gа нађетие gруїачији начин рјешавања овоі йроблема? Како знайе gа је ово ваљано?

\section{Шта је алгебра у раној алгебри?}

Предлог представљања алгебре у наставном програму математике за ниже разреде основне школе намеће неопходност широке дескрипције шта би требало разматрати у основношколској алгебри. Већи број истраживача математичког образовања настојао је да понуди промишљање о овом питању. Још увијек не постоји широки консензус о томе. Алгебра се сматрала језиком, начином мишљења, али и алатом за активну генерализацију аритметике. Џејмс Капут (Kaput, 1999) сублимирао је то на слиједећи начин:

- Генерализација шаблона и односа (специјална генерализација аритметичког и квантитативног промишљања);

- Функционално промишљање;

- Моделовање;

- Синтаксно вођена манипулација формулама;

- Проучавање структура.

Ова широка дескрипција омогућава инволвирање алгебре у наставни програм матема- 
тике за ниже разреде основне школе уз уважавање различитих приступа и пружа општу идеју о различитим аспектима алгебре.

\section{Рана алїебра и аритметика - инволвирање алгебарског мишљења у аритметику}

Многи истраживачи математичког образовања (на примјер, Жана Ејнли (Ainley, 2001), Луис Редфорд (Radford 2010, Radford 2012, Redford 2012 (у штампи)), Дејвид Карахер, Абалуција Шлиман и Барбара Бризуела (Carraher, Schliemann and Brizuela, 2001), Даниел Романо (Романо, 2009), Бирт Јулија Шпехт (Specht, 2005) и Дејвид Тол (Tall, 2001)), али и неки наставници математичких садржаја у нижим разредима основне школе прихватили су термин рана аліе $\delta a$, који покрива процес инволвирања алгебарских садржаја у подучавање аритметике. Ова рана аліе бра није баш иста као алгебра коју су упознали многи читаоци када су окончали више разреде основне школе и средњу школу. Знатан број особа који себе сматра познаваоцем домена

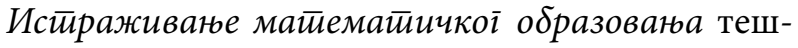
ко прихвата да у нашем школском систему реално постоји могућност да ученик оконча средњу школу а да му се математичко мишљење састоји само од аритметичког и наивногеометријског (на „нивоу 0“ и унутар „нивоа 1“ - по Ван Хиелеовој класификацији), тј. да није овладао бројним елементима алгебарског мишљења. Рана аліе бра се преплиће са традиционалним доменима унутар основношколских математичких курикулума уводећи алгебарску нотацију постепено. Она је у чврстој вези за обилношћу позадине контекста математичких проблема/задатака (Carraher, Schliemann and Schwartz, 2007). Многи од горе поменутих истраживача подупирали су став да раздвајање арирметике и алгебре продужава, али и продубљује, како ученичке потешкоће у разумијевању важних концепата који стоје у основи аритметике, тако и наставничке недоумице са потребом да се аритметички садржаји коректно преносе ученицима. Стога су препоручивали парцијално интегрисање ова два домена - убацивање алгебарских алата у аритметичке концепте гдје је то могуће. Традиционално, алгебра се подучава послије артиметике, када се процијени да су ученици овладали неопходним вјештинама у раду са објектима аритметичких структура, када се процијени да код ученика постоје способности које омогућавају прихватање алгебарског резоновања. Иако су многи односи међу објектима карактеристичних аритметичких структура хипотетички научени, процјењује се да је ученичко разумијевање фундаменталних математичких принципа, као што су особине асоцијативности, комутативности за операције сабирања и множења природних бројева, постојање неутрала за ове операције или, на примјер, корисне законе:

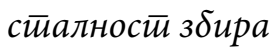

$$
\begin{array}{ll}
a+b=(a-c)+(b+c), & c \cdot a \\
a+b=(a+c)+(b-c), & c \cdot b
\end{array}
$$

оgузимане броја оg збира бројева

$$
\begin{gathered}
(a+b)-c=(a-c)+b \text { уз услов } c \cdot a \\
=a+(b-c), \text { уз услов } c \cdot b
\end{gathered}
$$

али и

$$
\begin{aligned}
(a+b)-c & =\left(a-c_{1}\right)+\left(b-c_{2}\right), \text { уз услов ga je } \\
c & =c_{1}+c_{2}, c_{1} \cdot a \text { u } c_{2} \cdot b,
\end{aligned}
$$

тj.

$$
\begin{gathered}
(a+b)-c=(a-d)+(b-(c-d)), \text { уз услов ga je } \\
d \cdot a u d \cdot c,
\end{gathered}
$$

али и многе друге правилности у раду са природним бројевима произашле из усвојених аритметичких алгоритама рачунања и интуитивног прихватања индуктивне генерализације знања. Како год било, истраживања показују да ученичке потешкоће у разумијевању алгебарских концепата инволвираних у аритметичке садржаје најчешће произлазе из учитељских лоших разумијевања значајности веза и математичких структура. Чини се да највећи број ученичких потешкоћа у раду са алгебром вуче коријене ди- 
ректно из слабог учитељског разумијевања аритметичких односа. Способност смисленог рада у алгебри, тиме и флуентно манипулисање алгебарским нотацијама, подразумијева да се код ученика прво развије способност семантичког разумијевања аритметике. Разумијевање и употреба особина операција добијених апстракцијом, тј. разумијевање унутрашње структуре операција и релација међу њима, заједно са способношћу везивања ових елемената са стварним ситуацијама, процјењује се, једно је од главних аспеката разумијевања аритметичких операција и релација. Усвајајући ове процјене као прихватљиве, ми промовишемо идеју кориштења повезивања алгебарских концепата са аритметичким садржајима при подучавању ученика математичким идејама у нижим разредима основне школе.

\section{Шта се подразумијева под синтагмом

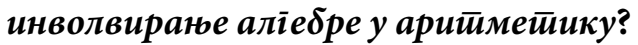

Кад кажемо да ученик везано размишља или да користи везано размишљање, онда мислимо на то да, када рјешава математички проблем, испитује двије или више математичких идеја алтернативно гледајући на везу између њих и анализирајући их, користи те односе у намјери да ријеши проблем, формира неку тврдњу или покаже да разумије ситуацију или концепт у који је укључен. У контексту аритметике, овај термин је схваћен у слиједећем смислу: „ученици могу да препознају много различитих односа између бројева, операција и релација са њима“ (Koehler, 2004; Molina, Castro and Ambrose, 2005). Овако разумијевање је од великог значаја у математици будући да многе основне математичке идеје укључују односе између различитих репрезентација бројева али и операција и релација између њих. Сматра се да је језгро математичког разумијевања успостављање односа између математичких идеја и концепата. Зато везано раз- мишљање омогућује да ученици остваре дубље разумијевање у аритметици. Након тога, апстракције које претходе уласку у алгебру, будући да су добро засноване, омогућавају квалитетније базирање основних компонената алгебарског размишљања. Везано размишљање се може развити на различитим активностима помажући ученицима да обрате пажњу на односе између бројева, с једне стране, и операција и релација, с друге стране. Ова знања не само да помажу у развијању аритметичког знања него оснажују вјештине рачунања. Да би се почело са оваквим начином размишљања, ученицима треба омогућавати да третирају математичке проблеме у којима су једначине и неједначине објекти који се анализирају. На ове последње не треба гледати само као на процесе којима ученици треба да буду вични. Ова дуалност „процесно/објекатско третирање концепата“ омогућава развијање способности код ученика да упоредо користе два модела размишљања. Ову повезаност Ана Сфард (Sfard, 1991) идентификовала је као фундаменталну способност у разумијевању алгебарских идеја. Многи математички задацима, посебно они које можемо окарактерисати као линеарни прости задаци и линеарно сложени задаци (или унутар SOLO-таксономије: задаци Преg-

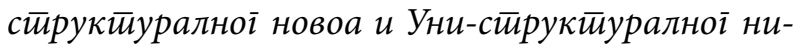
воа) не потражују дубље разумијевање једнакости. С друге стране, задаци које карактеришемо као нелинеарно сложени задаци и нестандард-

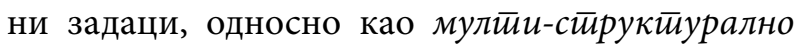
сложене, задаци на релационом нивоу, односно

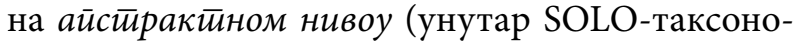
мије), захтијевају да знак једнакости представља упоредивост два исказа. Ове разлике се морају узимати у обзир када се ученици подучавају поступцима са бројевима будући да ученици основних школа најчешће третирају знак једнакости као сигнал да треба извршити нека израчунавања. Фокусирањем на сабирање и одузимање природних бројева идентификовали смо осам главних веза: 
- Комплементарност сабирања и одузимања;

- Комутативност сабирања;

- Збир два броја се не мијења када се исти број сабере са једним сабирком, а одузме од другог сабирка;

- Резултат одузимања се не мијења када се исти број сабере или одузме од оба

- $\quad$ члана;

- Нула је неутрал за сабирање;

- Када се број одузме од самог себе добија се нула;

- Асоцијативност сабирања;

- Сваки се број може на више начина приказати као збир два броја.

\section{Преглед}

Традиционални приступ реализацији наставе математике, у складу са одобреним наставним програмом (какав се његује у већини наших основних школа), не промовише промоцију везаног размишљања - инволвирање алгебарских садржаја у аритметику. Овакав закључак су потврдили и Ролин Либенберг, Марлин Сасман и Алвин Оливер у својим истраживањима (Liebenberg, Sasman and Olivier, 1999). Ови истраживачи су уочили да велика већина ученика нижих разреда основне школе није у стању да рјешава задатке отвореног типа. Процијењено је да то произлази из њиховог увјерења (које су стекли уз знатно наставничко сугерисање) да у добијању одговора на постављена питања треба и мора да постоји неко израчунавање које треба извршити. Овакво опредјељење ученика и усвојени ставови сигурно су преузети од њихових реализатора наставе математике будући да експонирају наставничко недовољно знање о аритметичким операцијама али и неразумијевање особина тих операција. Каролајн Киран (Kieran, 1997) изнијела је запажање да, при таквом принципијел- но-филозофском опредијељењу друштвене заједнице, ученици млађи од тринаест година нису у стању да из везаног размишљања извлаче користи при раду са бројевним изразима. Ови истраживачи су извели закључак да поменута ученичка ограничења произлазе из њиховог начина гледања на те изразе као објекте (цјеловите објекте), а не као на низ операција које треба урадити. Николас Хершкович и Лиора Линчевски (Herscovics and Linchevski, 1994) процјењивали су да ученичке потешкоће произлазе из когнитивне раздвојености аритметике и алгебре.

У скоријим истраживањима софистиранији приступ настави математике освијетлио је поменуте ученичке потешкоће. У истраживањима Јулије Кохлер (Kohler, 2004) „пет лоших ђака трећег и четвртог разреда основне школе су била у стању да развију знање о повезаности између бројева, операција и релација и бројевних израза али и да науче 'мултипликативне факте' са разумијевањем.“ Овим истраживањем је показано да, при промјени (теоријског) приступа настави математике, ученици не морају савршено да знају рачунање да би учествовали у развијенијим математичким активностима у учионици када је кориштено везано размишљање, тј. када је претходно преферирано укључивање елемената алгебарског мишљења у аритметику. У ствари, Кохлер је нашла да везано размишљање помаже при тежим облицима израчунавања. Томас Карпинтер, Линда Леви и Меган Франке (Carpenter, Franke and Levi, 2003), пратећи Дејвисов рад (Davis, 1964), изнијели су сугестију да се при подучавању ученика користе и тачни/нетачни низови да би ученици боље разумијели својства једнакости, али и за подстицање разумијевања везаног размишљања. Низови бројева пружају прилику да се отвори дискусија о повезаности између бројева и операција. Према процјенама Каролајн Киран (Kieran, 2004), трансформација од аритметике до алгебре се код многих ученика одвија са доста потешкоћа будући да алгебра од ученика потражује значајна прилагођавања. Она 
мисли да прихватљива трансформација од аритметике до алгебре захтијева:

а) фокусирање на везе између бројева а не само на рачунање тим бројевима;

б) фокусирање на операције али и на њихове инверзе, као и на концепте шта би требало, односно шта не би требало радити;

в) фокусирање на разумијевање шта проблем јесте а не само како га ријешити;

г) фокусирање на бројеве и на терме/слова а не само на бројеве;

д) преиспитивање значења знака једнакости.

Ових пет ученичких прилагођавања репрезентују неопходне промјене аспеката развоја фундаменталних идеја у преласку са аритметике на учење и разумијевање алгебре.

Наша запажања такође поткрепљују наша увјерења да се ученицима нижих разреда основне школе у нас треба омогућавати да развијају своје алгебарске способности унутар аритметике посредством везаног размишљања.

\section{Наша запажања}

Како бисмо детаљније испитали неке од ових идеја, посматрали смо кандидате на учитељском стручном испиту (реализован је за девет кандидата током два дана), који су имали тему „Одузимање броја од збира“. Часу су присуствовала два наставника, испитивач и ментор припрема/учитељ, у чијем одјељењу је реализован практични дио стручног испита (у Ocновној школи „Свети Сава“ у Бијељини). Усмени дио стручних испита реализован је уз присуство свих кандидата, свих ментора и чланова испитне комисије, што је омогућило да се отвори дискусија о инволвирању елемената алгебарског мишљења у аритметичке структуре при реализацији поменуте наставне јединице.

\section{Циљеви}

Циљеви који су били постављени:

- Препознавање правилности/шаблона у позадини нумеричких радњи;

- Схватање на који начин кориштење правилности/шаблона помаже течно рачунање;

- Схватање на који начин препознавање правилности/шаблона може водити до закључака;

- Стицање самопоуздања при кориштењу симбола у представљању било којег броја.

\section{Један примјер инволвирања алгебре у аритметичке структуре}

У обавезном уџбенику (Липовац, 2008) математике за трећи разред основне школе у Републици Српској, у тематској цјелини „Сабирање и одузимање бројева до 100“, у методској јединици „Одузимање броја од збира“ (Липовац, 2008: 49), понуђен је задатак и рјешење тог задатка:

Задатак. Уђачкој библиоиееци на йрвој йолиии има 35 книїа, а на gруїој 47. То је укуйно $35+47$ кюиі̄а. Зора је са йолица узела 27 кюиїа. Колико је књиі̄ остиало на обје йолице?

Рјешење. Овај задатак можемо урадити на три начина:

1. начин: Зора је могла узети потребне књиге са обје полице. Тада би израчунавање текло овако: $(35+47)-27=82-27=55$.

2. начин: Зора је могла да узме потребне књиге само са прве полице. Тада бисмо рачунали овако: $(35-27)+47=8+47=55$.

3. начин: Зора је могла да узме потребне књиге само са друге полице. Тада бисмо рачунали: $35+(47-27)=35+20=55$.

\section{4}


Резултати израчунавања на сва три начина су једнаки и сваки износи 55.

a) Да је Зора узела 40 књига, на колико начина би могла да узме књиге?

1) Са обје полице $(35+47)-40=82-40=42$.

2) Само са друге полице $35+(47-40)=35$ $+7=42$.

б) А да је узела 50 књига, могла би да узме књиге само на први начин, и то:

$(35+47)-50=82-50=32$.

Коментиар уз йосйављени заgайак. Каgа

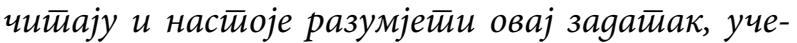
ници йрећеі разреgа основне школе у нас, у Рейублиии Срйској, вјеровайно мисле gа је Зора gије-

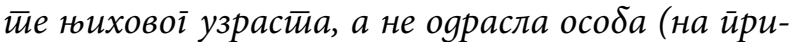
мјер, библиоиеккарка или иррояавачии, књиїа). Уз

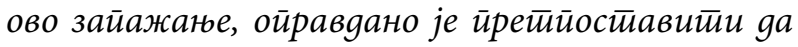
gјеца на заgатиак не ілеgају као на неки йосйуйак који је реално моі̄ућ: Како ће gијете узейи

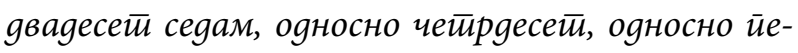
gесети книїа са gвије йолице? Чак и одрасла особа би имала ирроблема ирри узимаюу йоликоі број книїа. Уз иретитиостиавку gа је Зора особа која је вична у раgу са книїама (на йримјер, библиоиеекар или ӣродавач књиїа), може се йрочијенитии

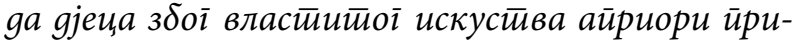

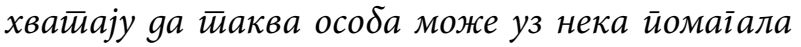
узетии йолики број књиіа са gвије йолище.

Иако аутор уџбеника није експлицитно исказао да се овај задатак може урадити само на три начина, такав се утисак стиче, и, вјерујемо, да га тако прихватају и учитељи и ученици. Аутори имају сазнања да неки учитељи инсистирају чак и на редослиједу начина показаних у овом уџбенику. Наравно, задатак је могуће урадити и на неке друге начине, осим оних које су описани у уџбенику.

Анализирајмо сада хипотетичку ситуацију: Претпоставимо да принципијелно-филозофско опредјељење наше друштвене и академске зајед- нице инкорпорирано у наставни програм математике за трећи разред основне школе није $\bar{u} р a g u-$

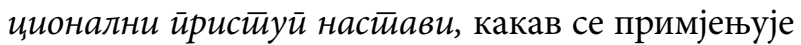
у већини наших основних школа, већ Теорија gugакииччких сийуација (Brousseau, 1997; Radford,

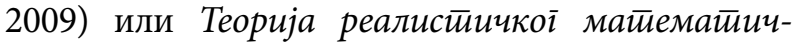
коі̄ образованьа (Freudenthal, 1991; Radford, 2009; Романо, 2009a; Van den Heuvel-Panhuizen, 1996). Тада би се подучавање ученика проблему „Одузимање броја од збира“ могло одвијати, на примјер, на слиједећи начин, који је као предлог реализације презентован кандидатима током разговора о могућим бенефитима инволвирања алгебарског аспекта у аритметику. (Ова презентација омогућава компарацију традиционалног приступа и раноалгебарског приступа подучавању ученика стратегијама одузимање броја од збира.) Овим приступом се постиже:

(a) генерализација аритметичких правилности;

(б) уочавање релацијских веза;

(в) фокусирање на разумијевање шта проблем јесте;

(г) фокусирање на бројеве и на слова; сти).

(д) преиспитивање значења знака једнако-

Наставник треба да препусти ученицима да сами изведу закључке о начинима рјешавања претходног задатка. Ученици треба сами да опишу ријечима како су ријешили задатак те да уз наставникову помоћ запишу те поступке. То би се, предвиђамо, одвијало овако (наравно, уз уважавање елемената scaffolding-a) или приближно овако:

Наставник: Xajge ga caga ойишемо искоришитене йосииуйке и gа их заиииемо.

Ученик: Ако не водимо рачуна са које полице је Зора узела књиге, онда од броја књига на обје полице $35+47$ треба одузети број 27 (у првом случају), број 40 (у другом случају) и број 50 (у трећем случају). Дакле, 
$(35+47)-27=55, \quad(35+47)-40=42$ и $(35+47)-50=32$.

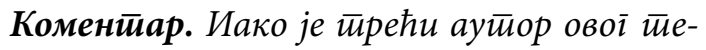
ксйа, иррисустивујући кандияайским иоказним часовима, сииекао уйисак gа ученици скоро без ироблема ояузимају gвоиифрене бројеве, ийак,

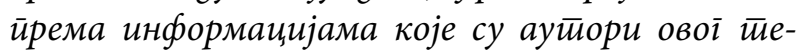
ксйа иррикуйили кроз разіооворе са немалим бројем учитиеть у бијетинским основним школама, зайажени су слијеgећи ирроблеми:

(1) Проблем одузимања једноцифрених бројева од двоцифрених бројева ако је задња цифра двоцифреног броја мања од умањиоца (на примјер, 43 - 8);

(2) Проблем одузимања двоцифрених бројева када је задња цифра умањиоца већа од задње цифре умањеника (на примјер, 82 - 27);

(3) Учитељи нису упознати са стратегијама сабирања и одузимања двоцифрених бројева.

Наставник: Словом с означимо број књи-

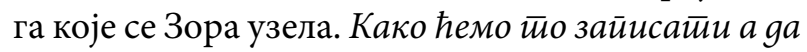
наш зайис йокрије сва йри случаја?

Ученик: $(35+47)-c$.

Наставник: Правилности које уочавамо у раду са бројевима зовемо шаблони. Да чујемо

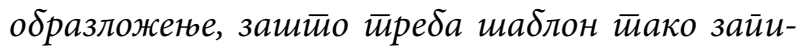
сайu?

Ученик: Када у запису $(35+47)$ - $c$ умјесто слова $c$ уврстимо 27 или 40 или 50, добићемо исте резултате као горе.

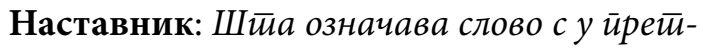
ходном зайису? Да ли је тио ознака само за бројева 27, 40 и 50 или може значитии и неке gруіе бројеBe?

Ученик: У нашем шаблону слово $c$ јесте ознака за бројеве 27, 40 и 50, али и све друге бројеве које можемо одузимати од збира $35+47$.
Наставник: Тачно йако. Али, gа ли знамо колико је с?

Ученик: Не знамо.

Наставник: Зашӣо не знамо?

Ученик: Зато што не знамо који број треба уврстити умјесто слова $c$.

Наставник: Дакле, не можемо израчунати колико је $(35+47)$ - $c$. Овај шаблон нам назначава да се од збира $35+47$ одузима неки број, али није речено који, па тако не знамо резултат одузимања. Резултат овиси од тога којим бројем замијенимо слово $c$. Будући да слово $c$ може бити било који од бројева од 0 до $35+47=82$, овако употребљено слово зовемо „промјенљива“ или „непознаница“.

Наставник: Хајдемо сад даље. Ойишимо сийуаиију каква се реално дешава каg се узимају книіе са йолиияа.

Ученик: Зора је могла узети све књига са прве полице, а остале са друге полице.

Наставник: Да. То је тачно. Како ћемо йо

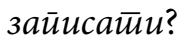

\section{Ученик:}

(a) први случај: $(35+47)-27=(35-27)+$ $(47-0)=8+47=55$,

(б) други случај: $(35+47)-40=(35-35)+$ $(47-5)=0+42=42$,

(в) трећи случај: $(35+47)-50=(35-35)+$ $(47-15)=0+32=32$.

Наставник: Да чујемо образложење. Заш-

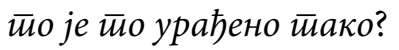

Ученик: У првом случају, када Зора узима 27 књига, могуће је да их узме са прве полице, будући да је 27 мање од 35. Тада је $35-27=8$. Преостаје да број 8 саберемо са бројем 47 и добијемо 55.

Наставник: Добро, али како ми знамо ga је 27 мање од 35?

Ученик: Имамо да је $27+8=35$. То значи да је 27 мање од 35. 


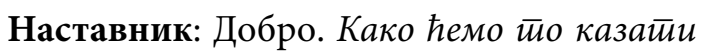
рјечима?

Ученик: Број 27 је мањи од броја 35, јер кад се броју 27 дода број 8 добије се број 35.

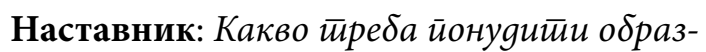
ложене за gруіи, односно йрећи случај?

Ученик: Када треба узети 40 књига са двије полице, мора се један број књига узети са друге полице, јер је број 40 већи од броја 35 . Како је $40=35+5$, могу се узети све књиге са прве полице, а осталих 5 са друге полице. (Код овог

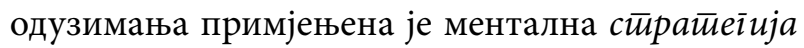
йреіруйисаюа бројева. Неки аутори ову стратегију називају Ogyзимане у guјеловима.) То изгледа овако:

$$
(35+47)-40=(35+47)-(35+5)
$$

Умањилац је записан као збир два броја.

$$
=(35-35)+(47-5)
$$

Извршено је прегруписање.

$$
=0+42=42
$$

Извршена су назначена одузимања.

Наставник: Како йо изіллеgа у йрећем случају, каgа се узима 50 књиіа?

Ученик: Ако треба узети 50 књига, са прве полице може се узети само 35, а остало се мора узети са друге полице. То записујемо овако:

$$
\begin{gathered}
50=35+15 \\
(35+47)-50=(35+47)-(35+15)= \\
(35-35)+(47-15)=0+32=42 .
\end{gathered}
$$

Наставник: Да ли йосӣоји и нека gруі̄а моiућности рачунаюа осим ове коју смо ми иримјенили?

Ученик: Да. Постоји. Постоји могућност да Зора узима прво књиге са друге полице, а потом са прве полице.

Наставник: Да чујемо gетиаљније образложене ових моїућностич.

\section{Ученик:}

(a) први случај: $(35+47)-27=(47-27)+$ $35=20+35=55$, (б) други случај: $(35+47)-40=(47-40)+$ $35=7+35=42$,

(в) трећи случај: Како је $50=47+3$, имамо $(35+47)-50=(47-47)+(35-3)=0+32=32$.

Наставник: Претпоставимо сада овакву ситуацију. Зора узима само неке књиге са једне полице али не све, а преостале са друге полице. Рецимо да Зора узима 13 књига са прве полице. Колико книїа узима са gруїе йолище? Како ће йаgа изілеgатии наше оgузимане?

Ученик: Колико ће књига Зора узети са друге полице, зависи од броја књига које укупно треба узети са обје полице. Имамо:

(a) први случај: Како је $27-13=14$, имамо $(35+47)-27=(35+47)-(13+14)=(35-$ 13) $+(47-14)=22+33=55$,

(б) други случај: Како је 40 - $13=27$, имамо

$(35+47)-40=(35+47)-(13+27)=(35-$ 13) $+(47-27)=22+20=42$,

(6) трећи случај: Како је 50 - $13=37$, имамо

$(35+47)-50=(35+47)-(13+37)=(35-$ 13) $+(47-37)=22+10=32$.

Наставник: Ако словом а означимо број књиі̄ на йрвој йолици, а словом $b$ број кюиїа на gруїој йолиии, како ћемо саgа зайисайи наша одузимана?

Ученик: Ако словом $а$ означимо број књига на првој полици, а словом $b$ број књига на другој полици, наша одузимања можемо записати овако:

$$
(a+b)-27,(a+b)-40,(a+b)-50 .
$$

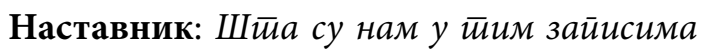
слова а и $b$ ?

Ученик: Слова $a$ и $b$ у овим шаблонима су непознанице јер не знамо који су то бројеви. Шаблони назначавају који поступак треба да урадимо.

Наставник: Сад нам преостаје да све ово што смо радили уредно запишемо. Имамо: 


$$
\begin{aligned}
& (a+b)-27=(a-27)+b \\
& \quad(\text { мора бити 27 } \bullet a) \\
& =a+(b-27) \quad(\text { мора бити } 27 \cdot b) \\
& =(a-13)+(b-14)
\end{aligned}
$$$$
\text { (мора бити } 13 \cdot a \text { и } 14 \cdot b \text { ) }
$$

У другом случају записујемо

$$
\begin{aligned}
& (a+b)-40=(a-40)+b \\
& \text { (мора бити } 40 \cdot a \text { ) } \\
& =a+(b-40) \\
& =(a-13)+(b-27) \\
& \text { (мора бити } 40 \bullet b \text { ) }
\end{aligned}
$$

(мора бити $13 \cdot a$ и $27 \cdot b$ ),

а у трећем случају имамо

$$
\begin{aligned}
& (a+b)-50=(a-50)+b \\
& \text { (мора бити } 50 \text { • a) } \\
& =a+(b-50) \\
& =(a-13)+(b-37) \\
& \text { (мора бити } 50 \bullet b \text { ) }
\end{aligned}
$$

(мора бити $13 \cdot a$ и $37 \cdot b$ ).

На крају нам преостаје да ово што смо радили лијепо искажемо ријечима. Одузимање једног броја од збира два броја може се обавити на више начина. Који начин ћемо употребити зависи од међусобних односа бројева о којима се конкретно ради у конкретном одузимању. Важно је да разумијемо идеју која се налази у основи ових израчунавања. Нашим записивањем помоћу слова само смо назначавали поступке које треба урадити.

\section{Мотиви за примјену везаног размишљања}

Фокусирајући се на учитељске активности пред, на и послије учитељских стручних испита, анализирали смо компетенције аритметичког и раноалгебарског мишљења кандидата. Примјетили смо да се сви кандидати, при показном часу у обради методске јединице „Одузимање броја од збира“, ослањају на своје и ученичке способ- ности разумијевања аритметике. У кандидатским припремама, у реализацији показног часа, али и за вријеме анализирања одржаног часа, нигдје није примјећена употреба елемената који би подстицали развој алгебарског мишљења код ученика. Нисмо установили да је неко од кандидата написао припреме и реализовао час са намјером да код ученика подстакне развој везаног мишљења - инволвирање елемената алгебарског мишљења у аритметичка размишљања. Током усмених разговора са кандидатима, неколико кандидата је поентирало да су свјесни могућности које пружа везано размишљање, али да га нису користили током реализације показног часа јер су се ослањали на обавезни школски уџбеник за трећи разред основне школе у Републици Српској, гдје таква могућност није предвиђена. Будући да се усмени дио кандидатских испита одвија уз присуство свих кандидата, било је могуће отворити дијалог о бенефитима које би имали ученици да су им се постављали захтијеви који подстичу алгебарско мишљење. Први доказ о кандидатским способностима да процјене оправданост везаног размишљања огледао се у њиховим настојањима да понуде оправдања за примјену поступка означених као „начин 1“, „начин 2“ или „начин 3“ у уџбенику. На испитивачево питање Како ће ученици йроијениватии који йреба начин йримејнитии ири йримјени ииехнолоїије рјешавань заgатиака ӣонуђених у ущбенику, али и тиоком реализације йоказної часа? сви кандидати су понудили промишљање да је неопходно да се сабирци у збиру упоређују са бројем који треба одузети од тог збира. На додатно питање Да ли йо су раgили? већина кандидата је одговорила потврдно, али да то нису посебно истицали.

На испитивачеву понуду кандидатима да моделирају и детаљно опишу и запишу куповину јаја код пијачних продавача, кандидати су се сложили да се поступак може описати на слиједећи начин или слично. 
Јаја се налазе у картонима за јаја у које стаје тридесет комада. Продавац прво покупи јаја из једног картона (ради одређености, рецимо да је у првом картону било 17 јаја или, на примјер, 33), а потом из другог картона (30 комада) покупи преостала јаја, до броја који је купац тражио (рецимо, 35). Овај поступак

$$
\begin{gathered}
(17+30)-35=(17+30)-(17+18)=(17-17)+ \\
(30-18)=0+12=12,
\end{gathered}
$$

односно

$$
\begin{gathered}
(33+30)-35=(33+30)-(33+2)=(33-33)+ \\
(30-2)=0+28=28,
\end{gathered}
$$

којим се израчунава колико је јаја остало у другом катрону, реалнији је и методски оправданији од било којег другог поступка. Дакле, прво упоредимо број $c$ који одузимамо од збира $a+b$ са сабирцима $a$ и $b$ али и са самим збиром $a+b$. Током тог упоређивања до изражаја долази ученичко разумијевање релације поретка међу природним бројевима. Имамо:

- ако је $c \cdot a$, можемо примјенити поступак $(a+b)-c=(a-c)+b$

- ако је $c \cdot b$, можемо примјенити поступак $(a+b)-c=a+(b-c)$

- ако је $a \cdot c$ и $b \cdot c$ a $c \cdot a+b$, можемо примјенити поступак

$$
(a+b)-c=(a-a)+(b-(c-a)) .
$$

Представимо умањилац $c$ као збир два броја. На примјер, $d+e=c$, при чему је број $d$ мање од броја $a$, а број $e$ од броја $b$. Сада имамо:

$(a+b)-c=(a+b)-(d+e)$ Умањилац је приказан као збир бројева.

$=(a-d)+(b-e)$ Извршено је прегруписање бројева.

(Подсјећамо да слово $d$ означава број књига које је Зора узела са прве полице, а слово $e$ број књига које је узела са друге полице. Може ли у једнакости $d+e=c$ један од бројева да буде нула? Шта то значи? Може. То значи да је Зора узела све књиге само са једне или само са друге полице). Ако је $d=0$, тада је $e=c$, па имамо

$$
a+(b-c) \text {. }
$$

(То значи да је Зора узела све књиге са друге полице). Ако је $e=0$, тада је $d=c$, имамо

$(a+b)-c$.

(Ово значи да су све књиге узете само са прве полице).

Коменйар. У йоку реализачије учи-

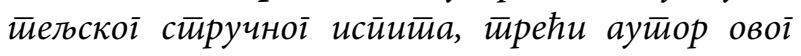

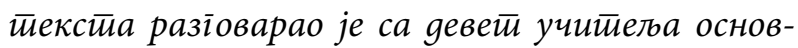
не школе „Светии Сава“ у Бијетини о уйотиреби шаблона са више оg gвије варијабле. Сем йоїа,

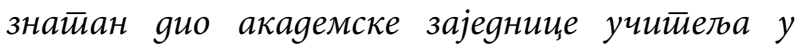
бијелинским основним школама (бивши сйуgен-

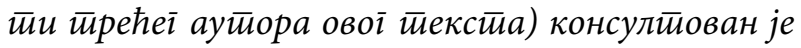

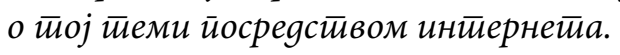

Готово сви саговорници са којима су се аутори консултовали током рада на овом тексту мисле да би употреба шаблона са више од двије варијабле ученицима представљала непремостиву препреку у разумијевању концепата. Неки од њих су ипак прихватали могућност да би се уочене правилности могле репрезентовати ученицима унутар реализације диференциране наставе али само за напреднију групу ученика. Трећи аутор овог текста заступа становиште да шаблони и њихово алгебарско записивање нису суштина инволвирања алгебре у аритметичке садржаје, већ само последица усвајања концепта рана алгебра. Наравно, алгебарску нотацију ученицима треба дозирати пажљивим испипавањем њихових рефлексија уз обавезу да их разумију, али без обавеза да их морају репродуковати.

Процијенимо који се циљеви наставе математике, осим когнитивних, могу досегнути назначеном промјеном приступа и реализацијом методске јединице на начин како је сугерисано. У домену афективних циљева наставе остварује се могућност да се подстиче развој аритметитичког 
мишљења. Такође, подстиче се и развој неких од елемената алгебарског мишљења будући да се отвара могућности да ученици буду подвргнути захтјевима да размишљају не само о међусобним односима бројева већ и на то како ће те односе описати ријечима, али и записивати алгебарским варијаблама/словима. Моделирање је поступак којим се контекстуални проблем преводи у математички - аритметички или алгебарски задатак (у овом случају). Притом, ученици су готово увјек у позицији да морају одлучивати да ли неки објект задовољава или не неки (додатни) захтјев. Дакле, ученици (уз наставникову помоћ) примјењују принцип искључења трећег, а понекад и принцип неконтрадикције. Ове активности, које реализатор наставе математике пажљиво дизајнира, подстичу развој елемената логичког мишљења код ученика. Сем тога, при оваквим моделирањима/рјешавањима задатака, уз наставнико непрекидно захтјевање од ученика да, описујући своје активности на објектима, стално процјењују шта се сматра прихватљивим рјешењем задатка/проблема - дакле, ученици усвајају неке од социо-математичких норми плански предвиђених за усвајање у трећем разреду основне школе.

Коменйар. Корисииимо се ирриликом gа йоgсјетиимо мане уйућеноі читиаоиа на неке оg

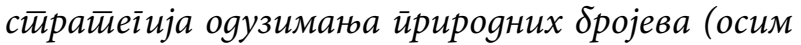

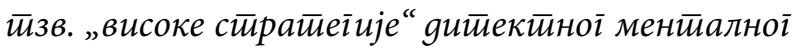
рачунана).

1. Скакање на бројној линији:

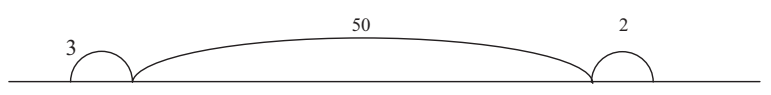

$27 \quad 30$

$80 \quad 82$

$$
27+\square=82
$$

2. Коришћење заокружених бројева:

$82-27=(82+3)-(27+3)=85-30=55$.

3. Стратегија „не одузимати већ сабирати“:
Треба израчунати 82 - 27.

Знамо да је $27+3=30$ и $30+50=80$ и $80+$ $2=82$. Дакле, резултат одузимања је

$3+50+2=55$.

4. Кад је један број близу 100 може се користити стратегија „заокруживања до 100“:

$82-27=(82+18)-(27+18)=(82+18)-$

$(20+7+10+8)=100-45=55$.

5. „Split“-стратегија

$82=70+12,27=20+7$

$82-27=(70+12)-(20+7)=(70-20)+(12$

$-7)=50+5=55$.

6. Стратегија постепеног одузимања

$82-27=82-2-20-5=80-20-5=60-5=55$.

\section{Завршне опсервације}

Како је речено раније, у току стручног учитељског испита свршених студената учитељског програма, посматрана је реализација наставе јединице „Одузимање броја од збира“. У анализи одржаних часова са кандидатима расправљано је о могућностима које нуди обавезни уџбеник математике за трећи разред основне школе у Републици Српској, али и могућностима које омогућава алгебарски приступ проблему. Кандидати су се сложили да инволвирање алгебарског приступа овом аритметичком проблему омогућава реализаторима наставе али и ученицима да знатно више продубе своја схватања о алгебри и о томе како се алгебра односи према аритметици. Могло би се процјенити да комбиновање знања из властитог школовања, математике која се учи на Педагошком факултету, али и властита искуства у раду са ученицима трећег разреда основне школе обогаћују учитељско разумијевање инволвирања алгебре у аритметичке садржаје, али и суптилније разумијевање аритметичких концепата. 
У последње три декаде значајан број истраживача математичког образовања али и математичара непрекидно је настојао да се елементи алгебре инкорпорирају у програме математике за ниже разреде основне школе (Davis, 1985, 1989; Davydov, 1991; Kaput, 1999). Неки од њих су систематски истраживали овај концепт. На примјер: Џејн Ејнли (Ainley, 1999), Карол Белисио, Каролајн Махер (Bellisio \& Maher, 1999); Мариа Блентон, Џејмс Капут (Blanton \& Kaput,
2000); Ана Паула де Авелар Брито-Лима, Жорге Тацисио да Роша Фалко (Brito-Lima \& Da Rocha Falcão, 1997; Da Rocha Falcão et al., 2000); Томас Карпинтер, Линда Леви (Carpenter \& Levy, 2000); Роберт Дејвис (Davis, 1971/72); Девид Славит (Slavitt, 1999).

Међународним настојањима концептуализације домена рана алїебра аутори дају свој допринос овим текстом.

\section{Литература}

- Липовац, Д. (2008). Майемайика 3. Источно Сарајево: Завод за уџбенике и наставна средства.

- Романо, Д. А. (2009а). Теорије математичког образовања, Први дио: Теорија реалистичког математичког образовања. ИМО, Вол. I, 1, 23-35.

- Романо, Д. А. (2009). Шта је алгебарско мишљење? МАТ-КОЛ, XV(2), 19-29.

- Ainley, J. (1999). Doing Algebra-Type Stuff: emergent algebra in the primary school. In: Zaslavsky, O. (Ed.). Proceedings of the Twenty Third Annual Conference of the International Group for the Psychology of Mathematics Education, Vol. 2 (9-16). Haifa, Israel.

- Ainley, J. (2001). Research forum: Early algebra. In: Van den Heuvel-Panhuizen, M. (Ed.). Proceedings of the $25^{\text {th }}$ Conference of the International Group for the Psychology of Mathematics Education, Vol.1 (129-159). Utrecht, The Netherlands.

- Bednarz, N., Radford, L., Janvier, B. and Lepage, A. (1992). Aritmetical and algebraic thinking in problemsolving. In: Geeslin, W. and Graham, K. (Eds.). Proceedings of the $16^{\text {th }}$ Conference of the International Group for the Psychology of Mathematics Education, Vol. 1 (65-72). Durham, NH.

- Bellisio, C. \& Maher, C. (1998). What kind of notation do children use to express algebraic thinking? In: Berenson, S. et al. (Eds.). Proceedings of the XX Annual Meeting of the North American Chapter of the International Group for the Psychology of Mathematics Education (161-165). Columbus, OH, ERIC Clearinghouse.

- Blanton, M. \& Kaput, J. (2000). Generalizing and progressively formalizing in a third grade mathematics classroom: Conversations about even and odd numbers. In: Fernández, M. (Ed.). Proceedings of the XXII Annual Meeting of the North American Chapter of the International Group for the Psychology of Mathematics Education (115). Columbus, OH, ERIC Clearinghouse.

- Blanton, M. and Kaput, J. (2003). Developing elementary teachers' „algebra eyes and ears“. Teaching Children Mathematics, 10 (2), 70-83.

- Booth, L. R. (1989). A question of structure or a reaction to: „the early learning algebra: a structural perspective“. In: Wagner, S. and Kieran, C. (Eds.). Research Issues in the Learning and Teaching of Algebra, Vol. 4 (57-59). Reston, VA: Lawrence Erlbaum Associates and NCTM.

- Brito-Lima, A. P. \& da Rocha Falcão, J. T. (1997). Early development of algebraic representation among 6-13 year-old children. In: Pehkonen, E. (Ed.). Proceedings of the $21^{\text {st }}$ Conference of the International Group for the Psychology of Mathematics Education, Vol. 2 (201-208). Lahti, Finland. 
- Brousseau, G. (1997). Theory of Didactical Situations in Mathematics. Kluwer: Academic Publisher.

- Carraher, D. W., Schliemann, A. D., \& Schwartz, J. L. (2007). Early algebra is not the same as algebra early. In: Kaput, J., Carraher, D. \& Blanton, M. (Eds.). Algebra in the early grades (235-272). Mahwah: Erlbaum.

- Carpenter, T. P. \& Levy, L. (2000). Developing conceptions of algebraic reasoning in the primary grades. (Res. Rep. 00-2). Madison, WI: National Center for Improving Student Learning and Achievement in Mathematics and Science.

- Carpenter, T. P., Leof Franke, M. and Levi, L. (2003). Thinking Mathematically: Integrating Arithmetic and Algebra in Elementary School. Portsmouth, NH, Heinemann.

- Carraher, D., Schliemann, A. \& Brizuela, B. (2001). Can young students operate on unknowns? In: Van den Heuvel-Panhuizen, M. (Ed.). Proceedings of the $25^{\text {th }}$ Conference of the International Group for the Psychology of Mathematics Education, Vol. 1 (130-140). Utrecht, The Netherlands.

- Da Rocha Falcao, J. T., Brito Lima, A. P., Araújo, C. R., Lins Lessa, M. M. \& Osório, M. O. (2000). A didactic sequence for the introduction of algebraic activity in early elementary school. In: Nakahara, T. \& Koyama, M. (Eds.). Proceedings of the $24^{\text {th }}$ Conference of the International group for the Psychology of Mathematics Education, Vol. 2 (209-216). Hiroshima, Japan.

- Davis, R. B. (1964). Discovery in mathematics: A text for teachers. Palo Alto, CA: Addison-Wesley.

- Davis, R. B. (1971/72). Observing children's mathematical behavior as a foundation for curriculum planning. The Journal of Children's Mathematical Behavior, 1 (1), 7-59.

- Davis, R. B. (1985). ICME-5 Report: Algebraic thinking in the early grades. Journal of Mathematical Behavior, 4, 195-208.

- Davis, R. B. (1989). Theoretical considerations: Research studies in how humans think about algebra. In: Wagner, S. \& Kieran, C. (Eds.). Research Issues in the Learning and Teaching of Algebra, Vol. 4 (266-274). Reston, VA, NCTM/Erlbaum.

- Davydov, V. (1991/1969). Soviet studies in mathematics education, Vol. 6. Psychological abilities of primary school children in learning mathematics. Reston, VA, NCTM.

- Freudenthal, H. (1991). Revisiting Mathematics Education. China Lectures. Dordrecht: Kluwer Academic Publishers.

- Herscovics, N. and Linchevski, L. (1994). A cognitive gap between arithmetic and algebra. Educational Studies in Mathematics, 27, 59-78.

- Kaput, J. (1999). Teaching and Learning a New Algebra. In: Fennema, E. and Romberg, A. T. (Eds.). Mathematics classrooms that promote understanding (133-155). Mahwah, New Jersey: Lawrence Erlbaum Associates.

- Kieran, C. (1997). Mathematical concept at the secondary school level: The learning of algebra and functions. In: Bednarz, N., Bryant, P. and Lee, L. (Eds.). Learning and teaching mathematics: An international perspectives (133-158). Psychology Press.

- Kieran, C. (2004). Algebraic Thinking in the Early Grades: What is it?. The Mathematics Educator, 8 (1), 139-151.

- Kindt, M. (1980). Als een kat om de hete algebrij [As a cat around the algebra]. De Wiskrant, Tijadschrift voor Nederlands Wiskundeonderwijs, 5(21), 155-157. 
- Koehler, J. L. (2004). Learning to think relationally: thinking relationally to learn. Dissertation Research Proposal, University of Wisconsin-Madison.

- Lee, L. (1996). An initiation into algebraic culture through generalization activities. In: Bednarz, N., Kieran, C. and Lee, E. (Eds.). Approaches to Algebra. Kluwer: Academic Publishing.

- Leron, U. (2010). Porijeklo matematičkog mišljenja. IMO, Vol. II, broj 2, 21-25.

- Liebenberg, R., Sasman, M. and Olivier, A. (1999). From Numerical Equivalence To Algebraic Equivalence. Mathematics Learning and Teaching Initiative (MALATI). Paper presented at the $5^{\text {th }}$ annual conference of the Mathematics Education Associations of South Africa (AMESA), Puerto Elizabeth, July 5-9.

- Linchevski, L. (1995). Algebra with numbers and arithmetic with letters: A definition of pre-algebra. Journal of Mathematical Behavior, 14, 113-120.

- Mason, J. (2012). What is Arithmetic? In: Van Zanten, M. (Ed.). Opbrengstgericht Onderwijs Rekenen! Wiskiunde? (11-24). Proceedings of the $30^{\text {th }}$ PANAMA Conference. Utrecht: Fisme.

- Molina, M., Castro E. y Ambrose R. (2005). Enriching Arithmetic Learning by Promoting Relational Thinking. The International Journal of Learning, 12(5), 265-270.

- Redford, L. (2006). Algebraic Thinking and Generalization of Patterns: A Semiotic Perspective. In: Alatorre, S., Cortina, J. L., Sáiz, M. and Méndez, A. (Eds.). Proceedings of the $28^{\text {th }}$ Annual Meeting of the North American Chapter of the International Group for the Psychology of Mathematics Education, Vol. 1 (2-21). Mérida, Yucatán, México.

- Radford, L. (2009). Teorije u matematičkom obrazovanju: Jedna kratka studija o njihovim konceptualnim razlikama, IMO, Vol. I, broj 1, 11-22.

- Radford, L. (2010). Elementary forms of algebraic thinking in young students. In: Pinto, M. F. \& Kawasaki, T. F. (Eds.). Proceedings of the $34^{\text {th }}$ Conference of the International Group for the Psychology of Mathematics Education, Vol. 4 (73-80).

- Radford, L. (2012). On the development of early algebraic thinking. PNA, 6 (4), 117-133.

- Radford, L. (2012 - In press). Early algebraic thinking epistemological, semiotic and developmental issues. Proceeding of the $12^{\text {th }}$ International Congress on Mathematical Education. COEX, Seoul, Korea (In press).

- Sfard, A. (1991). On the dual nature of mathematics conceptions: Reflections on processes and objects as different sides of some coin. Educational Studies in Mathematics, 22, 1-36.

- Slavit, D. (1999). The role of operation sense in transitions from arithmetic to algebraic thought. Educational Studies in Mathematics, 37 (3), 251-274.

- Specht, B. J. (2005). Early Algebra - Processes and Concepts of Fourth Grades Solving Algebraic Problems. In: Bosch, M., Perpiñán, M., Àngels Portabella, M. and Llull, R. (Eds.). Proceedings of the $4^{\text {th }}$ Congress of the European Society for Research in Mathematics Education (706-716). Sant Feliu de Guíxols, Spain.

- Tall, D. O. (2001). Reflection on Early Algebra. In: Van den Heuvel-Panhuizen, M. (Ed.). Proceedings of the $25^{\text {th }}$ Conference of the International Group for the Psychology of Mathematics Education, Vol. 1 (149-152). Utrecht, The Netherlands.

- Van den Heuvel-Panhuizen, M. (1996). Assessment and Realistic Mathematics Education. Utrecht: CD-Beta Press. Also publ. as thesis Universiteit Utrecht. 


\begin{abstract}
Summary
This text is our contribution to conceptualization of the domain early algebra and the term early algebraic thinking in our primary school education. The paper describes arithmetic-early algebraic thinking about early numeric operations of graduated students from the faculties of education. According to this curriculum, students are expected to deal with algebraic ideas referring to many concepts of natural numbers, and we can form the hypothesis that students can connect what they have learnt at the course Teaching Methodology of Mathematics with their knowledge about arithmetic concepts within the semi circle of natural numbers. We justified this hypothesis by interviews with candidates at teachers' exams, and we dealt with algebraic contents incorporated into same arithmetic concepts. This text about involving algebraic ideas into algebraic concept of "subtracting the number from the sum" is a partial review about these interviews. Based on our knowledge about the mentioned talks with candidates, and on this occasion they were given the possibility of realization of this teaching unit accepting the concept of early algebra, so we can estimate that candidates are capable of making a certain connection, but that there are individual differences in achievement in these connections..
\end{abstract}

Key words: arithmetic and early algebraic thinking. 